\title{
Monitoring gene expression changes in bovine oviduct epithelial cells during the oestrous cycle
}

\author{
S Bauersachs, S Rehfeld, SE Ulbrich1, S Mallok², K Prelle, H Wenigerkind ${ }^{3}$, \\ R Einspanier ${ }^{1}$, H Blum ${ }^{2}$ and E Wolf
}

\author{
Institute of Molecular Animal Breeding, Ludwig Maximilians University, Feodor-Lynen-Str. 25, 81377 Munich, Germany \\ ${ }^{1}$ Institute of Physiology, Technical University of Munich, Weihenstephaner Berg 3, 85354 Freising, Germany \\ ${ }^{2}$ Gene Centre of the Ludwig Maximilians University, Feodor-Lynen-Str. 25, 81377 Munich, Germany \\ ${ }^{3}$ Bavarian Research Centre for Biology of Reproduction, Hackerstr. 27, 85764 Oberschleissheim, Germany \\ (Requests for offprints should be addressed to E Wolf; Email: ewolf@Imb.uni-muenchen.de) \\ (K Prelle is now at CRBA Gynecology \& Andrology, Schering AG, Muellerstr. 178, 13442 Berlin, Germany) \\ (R Einspanier is now at Institute of Veterinary Biochemistry, Free University of Berlin, Oertzenweg 19b, 14163 Berlin, Germany)
}

\begin{abstract}
The oviduct epithelium undergoes marked morphological and functional changes during the oestrous cycle. To study these changes at the level of the transcriptome we did a systematic gene expression analysis of bovine oviduct epithelial cells at oestrus and dioestrus using a combination of subtracted cDNA libraries and cDNA array hybridisation. A total of 3072 cDNA clones of two subtracted libraries were analysed by array hybridisation with cDNA probes derived from six cyclic heifers, three of them slaughtered at oestrus and three at dioestrus. Sequencing of CDNAs showing significant differences in their expression levels revealed 77 different cDNAs. Thirty-seven were expressed at a higher level at oestrus, for the other 40 genes expression levels were higher at dioestrus. The identified genes represented a variety of functional classes. During oestrus especially genes involved in the regulation of protein secretion and protein modification, and mRNAs of secreted proteins, were up-regulated, whereas during dioestrus particularly transcripts of genes involved in transcription regulation showed a slight up-regulation. The concentrations of seven selected transcripts were quantified by real-time RT-PCR to validate the cDNA array hybridisation data. For all seven transcripts, RT-PCR results were in excellent correlation $(r 0.92)$ with the results obtained by array hybridisation. Our study is the first to analyse changes in gene expression profiles of bovine oviduct epithelial cells during different stages of the oestrous cycle, providing a starting point for the clarification of the key transcriptome changes in these cells.
\end{abstract}

Journal of Molecular Endocrinology (2004) 32, 449-466

\section{Introduction}

The oviduct epithelium is important for different reproductive processes and undergoes marked morphological and functional changes during the oestrous cycle. It has been shown that a dramatic change in the frequencies of ciliated and nonciliated cells occurs during the oestrous cycle (Yaniz et al. 2000). At pre-oestrus the epithelium consists mainly of secretory cells and at dioestrus of ciliated cells. A recent study implies that the individual epithelial cells change their functional status, rather than the whole cell population being renewed, during the oestrous cycle (Suuroia et al. 2002).
The oviduct is responsible for the transport of ova, sperm and embryos, and the oviduct epithelial cells are the first to have contact with the ova and the cleavage-stage embryos. The isthmus part is described as functioning as a sperm reservoir sperm adhere to the epithelium and at the time of ovulation they are released (Hunter \& Wilmut 1984) to ensure the perfect timing of fertilisation. In this way, the oviduct provides the microenvironment for sperm capacitation, fertilisation, and early embryonic development (Buhi 2002).

At the molecular level only few genes or proteins are known that change in activity or abundance during the oestrous cycle and may be important for 
fertility, such as the bovine oviduct-specific glycoprotein, the major secretory protein in the oviduct (Boice et al. 1990). This protein has been described as having a positive influence on sperm capacitation and motility, the interaction of the gametes and fertilisation (for a review, see Buhi 2002). The expression of this glycoprotein is oestrogen-dependent with the highest level at oestrus and the lowest in the luteal phase. However, the production of a null mutation of the oviduct-specific glycoprotein (OVGP1) gene in a recent study in the mouse showed that fertility of ovgp $1^{-1-}$ females was in normal limits, indicating that OVGP1 is not essential for fertilisation (Araki et al. 2003).

Recently, we did a first systematic analysis of gene expression in bovine oviduct epithelial cells at day 3.5 of the oestrous cycle comparing the ipsilateral and the contralateral oviduct (Bauersachs et al. 2003). For that study we successfully used a combination of subtracted cDNA libraries and cDNA array hybridisation to identify cDNAs differentially regulated in the ipsi- vs the contralateral oviduct. In the present study we investigated the mRNA expression profile in epithelial cells of the ipsilateral oviduct at oestrus and dioestrus to provide a starting point for the identification of key transcriptome changes during the oestrous cycle. The results obtained by cDNA array hybridisation were verified for seven selected transcripts by absolute quantification using a real-time RT-PCR approach.

\section{Materials and methods}

\section{Synchronisation of oestrous cycle and isolation of oviduct epithelial cells}

Six cyclic heifers (Deutsches Fleckvieh) between 22 and 36 months old were treated with a progesterone $\left(\mathrm{P}_{4}\right)$-releasing intravaginal device $\left(1.94 \mathrm{~g} \mathrm{P}_{4}\right)$ (EAZI-Breed CIDR; Animal Reproductive Technologies Ltd, Leominster, Hereford and Worcs, UK) for 11 days beginning at dioestrus. After removal a single dose of $500 \mu \mathrm{g}$ cloprostenol (Estrumate; Essex Tierarznei, Munich, Germany) was administered i.m. Animals were observed for sexual behaviour (i.e. toleration, sweating, vaginal mucus) to determine standing heat, which occurred around $60 \mathrm{~h}$ after Estrumate injection. Three animals (group A) were slaughtered the morning after standing heat occurred and three animals (group B) 12 days after oestrus. Blood samples were taken just before slaughtering to determine $\mathrm{P}_{4}$ serum levels. Group A animals displayed low serum $\mathrm{P}_{4}$ levels $(<3.0 \mathrm{ng} / \mathrm{ml})$ and group $\mathrm{B}$ animals had high serum $\mathrm{P}_{4}$ levels $(>12 \cdot 0 \mathrm{ng} / \mathrm{ml})$. Oviducts were trimmed free of surrounding tissue and ligated at the infundibulum and at the isthmus-uterus junction. The complete organs were rinsed with PBS. After opening the oviduct longitudinally, epithelial cells were isolated by scraping the mucosal epithelial layer with a sterile glass slide (Reischl et al. 1999). Within 10 min after death cells were transferred into cryotubes and immediately dropped into liquid nitrogen for transport, and were stored at $-80{ }^{\circ} \mathrm{C}$ until further processing. All experiments with animals were carried out with permission from the local veterinary authorities.

\section{Oligonucleotides for suppression subtractive hybridisation (SSH)}

The following oligonucleotides were used for SSH: cDNA primer 1: AACTGGGGGCGGGTA $\mathrm{CAGCT}_{20} \mathrm{VN}(\mathrm{V}=\mathrm{A}, \mathrm{C}$ or $\mathrm{G})$, cDNA primer 2: GAGAT $_{20} \mathrm{VN}$, adapter 1: 5'-GTAATACGACTC ACTATAGGGCTCGAGCGGGCGGCAGGGC AGTG-3', adapter 1 reverse: 5'-CACTGCCGTG CGGG-3', adapter 2: 5'-GTAATACGACTCAC TATAGGGCAGGGCGTGGTGCGCGCTGC TGG-3', adapter 2 reverse: 5'-CGAGGAGCGG GCAG-3', PCR primer 1: 5'-GTAATAGGACT CACTATAGGGC-3', nested primer 1: 5'-TCG AGGGGGCGGCAGGGCAGTG-3', and nested primer 2: 5'-AGGGGGTGGTGGGGGGTGG TGG-3'.

\section{Generation of subtracted cDNA libraries}

The production of subtracted libraries was done according to the SSH method (Diatchenko et al. 1996, 1999, Gurskaya et al. 1996). Total RNA from bovine oviduct epithelial cells was isolated using Trizol (Invitrogen) according to the manufacturer's instructions. For each stage of the cycle, oestrus and dioestrus, RNA of two animals was pooled. Double-stranded (ds) cDNA was synthesised starting with $80 \mu \mathrm{g}$ total RNA (corresponding to approximately $1 \cdot 5-2 \mu \mathrm{g}$ mRNA) using Superscript II (400 U) (Invitrogen) and cDNA primer 1 $(50 \mathrm{pmol})$ for first-strand synthesis. The second 
strand was synthesised with Escherichia coli DNA polymerase I (40 U), E. coli RNase H (2 U), and $E$. coli DNA ligase (10 U) (Invitrogen) according to the manufacturer's instructions. Ribosomal and other residual RNAs were digested with $3 \mu \mathrm{l}$ RNase $(0.5 \mathrm{mg} / \mu \mathrm{l}$, DNase-free, from bovine pancreas; Roche Diagnostics) for $90 \mathrm{~min}$ at $37^{\circ} \mathrm{C}$. cDNA was then incubated with $10 \mathrm{U} \mathrm{T}$ 4 DNA polymerase (Roche) $\left(5 \mathrm{~min}\right.$ at $\left.16{ }^{\circ} \mathrm{C}\right)$ to yield blunt ends. After phenol/chloroform extraction and DNA precipitation cDNA was digested with RsaI (Roche). Tester cDNA was ligated with adapter $1 / 1$ rev or adapter 2/2 rev overnight at $16{ }^{\circ} \mathrm{C}$ using T4 DNA ligase (400 U; New England Biolabs). The first step of $\mathrm{SSH}$ was performed in $4 \mu \mathrm{l}$ for $8 \mathrm{~h}$ and the second hybridisation in $9 \mu \mathrm{l}$ for $20 \mathrm{~h}$ at $68^{\circ} \mathrm{C}$. Excess of driver was 30-fold in the first step of SSH. Suppression PGR was performed with the following parameters for primary PCR reactions: $75{ }^{\circ} \mathrm{C}$ for $5 \mathrm{~min} ; 96{ }^{\circ} \mathrm{C}$ for $60 \mathrm{~s} ; 29$ cycles (dioestrus) or 31 cycles (oestrus) at $\left(94{ }^{\circ} \mathrm{C}\right.$ for $30 \mathrm{~s}, 66^{\circ} \mathrm{C}$ for $30 \mathrm{~s}$, $72{ }^{\circ} \mathrm{C}$ for $1.5 \mathrm{~min}$ ); $72{ }^{\circ} \mathrm{C}$ for $3 \mathrm{~min}$. PCR products were diluted 10 -fold and $1 \mu$ of the dilution was used as a template for secondary PCR. This reaction was performed using nested primers with the following parameters: $96{ }^{\circ} \mathrm{C}$ for $1 \mathrm{~min} ; 12$ cycles (dioestrus) or 14 cycles (oestrus) at $\left(94^{\circ} \mathrm{C}\right.$ for $30 \mathrm{~s}, 68^{\circ} \mathrm{C}$ for $30 \mathrm{~s}, 72{ }^{\circ} \mathrm{C}$ for $\left.1.5 \mathrm{~min}\right) ; 72^{\circ} \mathrm{C}$ for 3 min. All PGR reactions were done in a Perkin Elmer Cetus thermal cycler using the Advantage 2 Polymerase Mix (BD Clontech, Heidelberg, Germany). After phenol/chloroform extraction and DNA precipitation PCR products were digested with BssHII (New England Biolabs) (inside the adapter sequences), purified by agarose gel electrophoresis, and ligated overnight with the AscI-digested (New England Biolabs) and dephosphorylated vector DNA (derivative of pBSIISK $^{-}$; Stratagene). The ligation reaction was introduced directly into $E$. coli SURE (Stratagene) by electroporation. The subtracted libraries were stored as glycerol stocks at $-80{ }^{\circ} \mathrm{C}$.

\section{Preparation of cDNA arrays}

cDNA array hybridisation was done essentially as previously described (Bauersachs et al. 2003). In brief, 1536 cDNA clones were randomly picked for each library and grown overnight at $37^{\circ} \mathrm{C}$ in $100 \mu \mathrm{l}$ LB medium in 96-well microtitre plates. Bacterial suspensions were diluted 20-fold in
Tris/HCl-EDTA(TE) buffer (pH 8.0), incubated at $96{ }^{\circ} \mathrm{C}$ for $10 \mathrm{~min}$, and stored at $-20^{\circ} \mathrm{C}$. PGR amplification of the cDNA insertions was performed in $20 \mu \mathrm{l}$ in 96-well cycle plates and contained $1 \mu$ diluted bacterial cells, PGR buffer (peQLab, Erlangen, Germany), $200 \mathrm{pmol} / \mu \mathrm{l}$ dNTPs, $0.3 \mathrm{pmol} / \mu \mathrm{l}$ of the respective primers (modified T3 and T7 primers), and $1 \mathrm{U}$ Taq DNA polymerase (peQLab). All PGR products were analysed by $0 \cdot 8 \%$ agarose gel electrophoresis showing that more than $95 \%$ of the PCR reactions yielded defined PCR products. Fifteen microlitres of PGR reactions were transferred to 384-well microtitre plates (Nunc) containing $15 \mu \mathrm{l} \mathrm{2-fold}$ spotting buffer (40 mM Tris- $\mathrm{HCl} \mathrm{pH}$ 8, $2 \mathrm{M} \mathrm{NaCl}$, 2 mM EDTA, bromophenol blue). A total of 1536 PCR products were spotted onto nylon membranes (Nytran Supercharge; Schleicher \& Schuell, Dassel, Germany) on an area of $20 \times 50 \mathrm{~mm}$ using an Omnigrid Accent microarrayer (GeneMachines, San Carlos, CA, USA) and solid pins (SSP015, diameter 0.015 inches; Telechem International, Sunnyvale, CA, USA). Spotting was done six times for each PGR product on the same position for sufficient and equal application; 25 arrays were produced simultaneously. The overall 3072 PCR products had to be distributed on two arrays that contained 1536 cDNAs $(768$ cDNAs of each subtracted library per array). The spotted cDNAs were denatured on the arrays by incubation on filter paper (Schleicher \& Schuell) soaked with $0.5 \mathrm{M} \mathrm{NaOH}$ for $20 \mathrm{~min}$ at room temperature. DNA was fixed by baking at $80^{\circ} \mathrm{C}$ for $30 \mathrm{~min}$ and UV cross-linking $\left(120 \mathrm{~mJ} / \mathrm{cm}^{2}\right)$ (XL-1500 UV Crosslinker; Spectronics Corp., New York, USA).

\section{cDNA array hybridisation}

RNA of all six animals (oestrus $n=3$, dioestrus $n=3$ ) was converted to ds cDNA essentially as described above but using cDNA primer 2. ${ }^{33}$ P-labelled cDNA probes were generated from ds cDNA corresponding to $7 \cdot 5-15 \mu \mathrm{g}$ total RNA. cDNA was heatdenatured for $10 \mathrm{~min}$ at $96{ }^{\circ} \mathrm{C}$ and then chilled on ice. High Prime reaction mixture (Roche), dNTP mixture (dCTP final concentration $10 \mathrm{pmol} / \mu \mathrm{l}$, dATP, dGTP, and dTTP final concentration each $100 \mathrm{pmol} / \mu \mathrm{l})$ and $90 \mu \mathrm{Ci}\left[\alpha-{ }^{33} \mathrm{P}\right] \mathrm{dCTP}$ were added to a final volume of $20 \mu \mathrm{l}$. Reactions were incubated for $4 \mathrm{~h}$ at $37^{\circ} \mathrm{C}$ and subsequently purified with MicroSpin G-25 Columns (Amersham Biosciences) 
to remove unincorporated nucleotides and to estimate labelling efficiency. Hybridisation was done as follows: pre-hybridisation was done for up to six arrays together in one $15 \mathrm{~cm}$ glass hybridisation bottle: $3 \times 10 \mathrm{~min} 10 \mathrm{ml} 1 \times \mathrm{PBS} / 10 \% \mathrm{SDS}$ at $65{ }^{\circ} \mathrm{C} ; 2 \times 10 \mathrm{~min} 10 \mathrm{ml} 0 \cdot 1 \times \mathrm{PBS} / 1 \% \mathrm{SDS}$ at $85^{\circ} \mathrm{C} ; 3 \times 10 \mathrm{~min} 10 \mathrm{ml} 1 \times \mathrm{PBS} / 10 \%$ SDS at $65^{\circ} \mathrm{C}$. Hybridisation probes were denatured for $15 \mathrm{~min}$ at $96{ }^{\circ} \mathrm{C}$ immediately before adding to the hybridisation solution. Hybridisation was done in plastic vials (Poly-Q vials, $18 \mathrm{ml}$; Beckman Coulter, Munich, Germany) in $2 \mathrm{ml} 1 \times \mathrm{PBS}, \mathrm{pH} 7 \cdot 5 / 10 \%$ SDS for $45 \mathrm{~h}$ at $65{ }^{\circ} \mathrm{C}$. After hybridisation, arrays were put together in one $15 \mathrm{~cm}$ glass hybridisation bottle and washed as follows: $3 \times 5 \mathrm{~min} 10 \mathrm{ml}$ $1 \times \mathrm{PBS} / 10 \% \mathrm{SDS}$ at $65{ }^{\circ} \mathrm{C} ; 3 \times 10 \mathrm{~min} 10 \mathrm{ml} 1 \times$ $\mathrm{PBS} / 10 \%$ SDS at $65^{\circ} \mathrm{C} ; 3 \times 10 \mathrm{~min} 10 \mathrm{ml}$ $0 \cdot 1 \times \mathrm{PBS} / 1 \% \mathrm{SDS}$ at $65{ }^{\circ} \mathrm{C}$ and finally $2 \times 5 \mathrm{~min}$ $10 \mathrm{ml} 1 \times \mathrm{PBS} / 1 \% \mathrm{SDS} / 2 \mathrm{mM}$ EDTA at room temperature. Filters were dried by baking at $80{ }^{\circ} \mathrm{C}$ for $20 \mathrm{~min}$ and exposed to an imaging plate BAS-SR (Fuji Photo Film Co.) Imaging plates were scanned with a phosphor imager (Storm 860; Amersham Biosciences).

To facilitate optimal evaluation of the hybridisation signals, 212 of the 3072 cDNA fragments were removed from the arrays due to their very high signal intensity that interfered with the analysis of approximately $20 \%$ of all signals; 103 cDNA fragments were from the oestrous library and 109 from the dioestrous library. Hybridisation of the arrays with the cDNA for bovine mRNA for $95 \mathrm{kDa}$ OVGP1 showed that approximately 70 cDNA fragments corresponded to the OVGP1 cDNA. The OVGP1-positive cDNA fragments came from the oestrous library and showed higher expression at oestrus. The cDNAs that were removed in addition to the OVGP1 cDNAs showed no differential signals between oestrus and dioestrus.

These optimised arrays were used for the final hybridisation analysis as described above.

\section{Analysis of array data}

Array evaluation was done using AIDA Image Analyzer (Version 3.27; Raytest, Straubenhardt, Germany). Background was subtracted with the 'Weighted background dot' function. Raw data obtained by AIDA Array software were exported to Microsoft Excel and normalised to the median of each array. These normalised values of the six hybridisation experiments were then used for statistical analysis (Student's $t$-test). Differences were considered significant at $P<0.05$ and a ratio $\geq 1 \cdot 5$. Reproducibility of the used array system was shown previously (Bauersachs et al. 2003).

\section{Sequencing of cDNAs with differential hybridisation signals and data analysis}

cDNA fragments showing differential hybridisation signals were sequenced directly from spotting solutions by automated DNA sequencing (3100Avant Genetic Analyzer; Applied Biosystems, Langen, Germany). Resulting sequences were compared with public sequence databases using the basic local alignment search tool at the National Centre for Biotechnology Information (http:// www.ncbi.nlm.nih.gov/blast/blast.cgi). cDNAs without similar entries in the 'nr' database (all GenBank+RefSeq Nucleotides+EMBL+DDBJ+ PDB sequences, but no EST, STS, GSS, or phase 0,1 or 2 HTGS sequences) were in addition compared with themselves to find redundant cDNA fragments. Based on the human or mouse homologues simplified Gene Ontologies were built using GeneSpring software version 6.1 (Silicon Genetics, Redwood City, CA, USA). Data from other sources, for example UniGene (www.ncbi.nlm.nih.gov/uniGene/), LocusLink (www. ncbi.nlm.nih.gov/locusLink/), and PubMed (www. ncbi.nlm.nih.gov/entrez/query.fcgi), were also integrated. The obtained sequences were submitted to dbEST (a division of GenBank).

\section{Primer pairs for real-time RT-PCR}

The following primers were used to amplify specific fragments referring to selected regulated genes (for abbreviations see Table 1, length of PCR products in square brackets): TRAl (for 5'-TGGCAGAG ACGATGGAAAG-3'; rev 5'-GGTAACTTCGC CTTCAGCAG-3' [120 bp]), ERP70 (for 5'-TCGA CTACATGATGGAGCAG-3'; rev 5'-CGGACT TAAAGACTCGGATG-3' [117 bp]), GRP78/ HSPA5 (for 5'-AACGACGCGTGACGAAAG AC-3'; rev 5'-TCACTCGAAGAATGCGATTC AG-3' [129 bp]), AGR2 (for 5'-AACTCAAAC TGCCCCAGACG-3'; rev 5'-ACAAACTGCTC TGGGAATCTC-3' [205 bp]), OVGP1 (for 5'-TG TCGACGTTTTCGAACGG-3'; rev 5'-GGAGG 

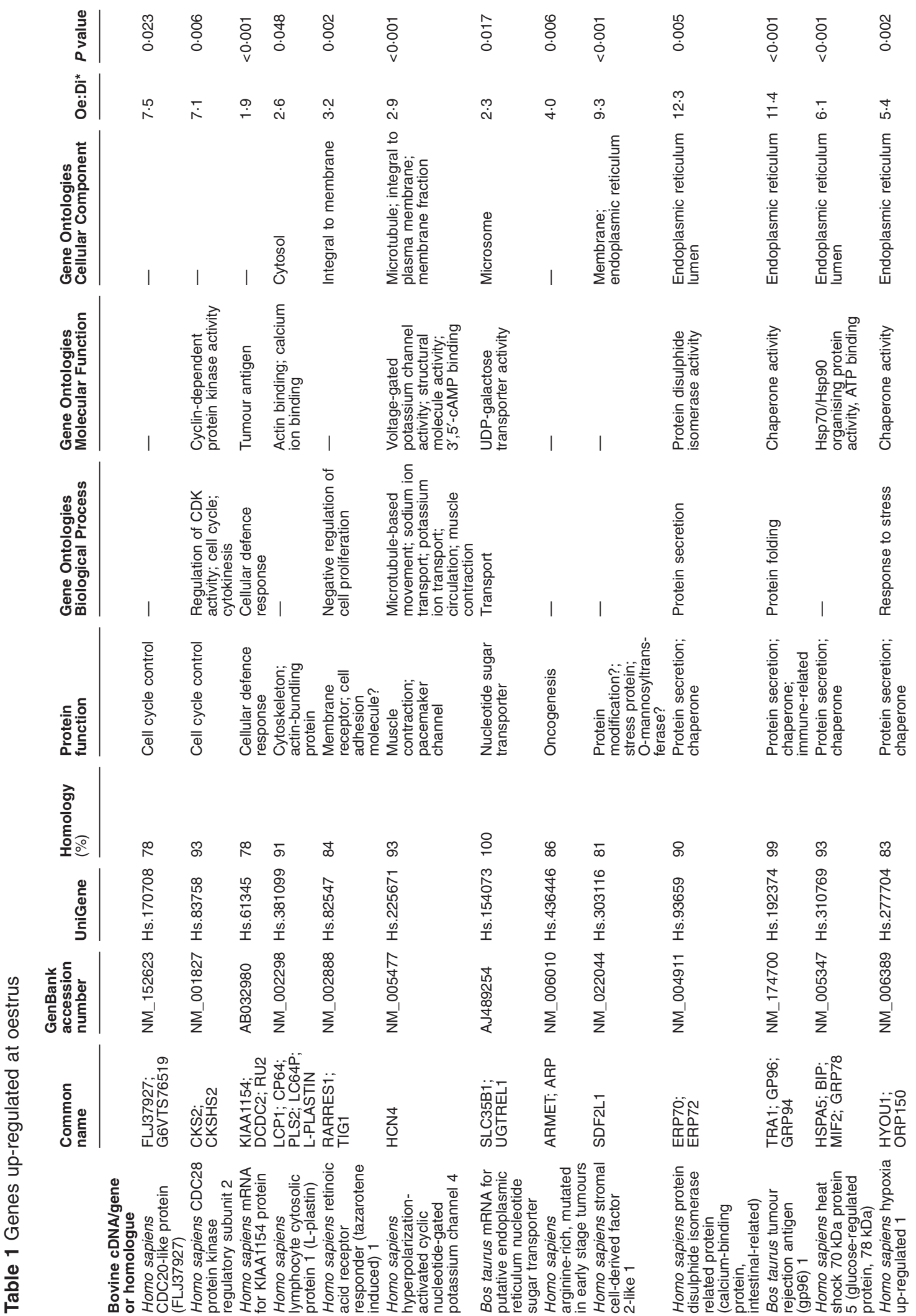


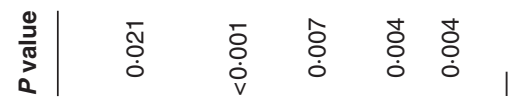

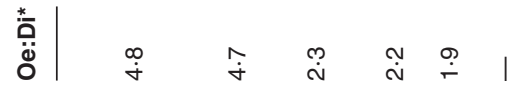

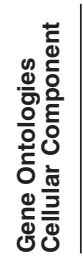
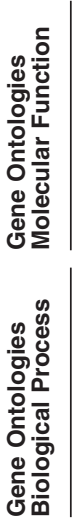

들ำ

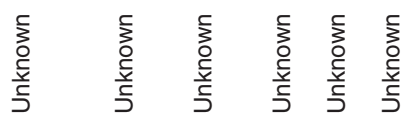

항|

ஃ ஃ \& คे ㄴ ।

夰

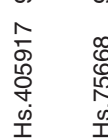

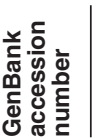

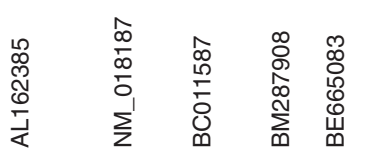

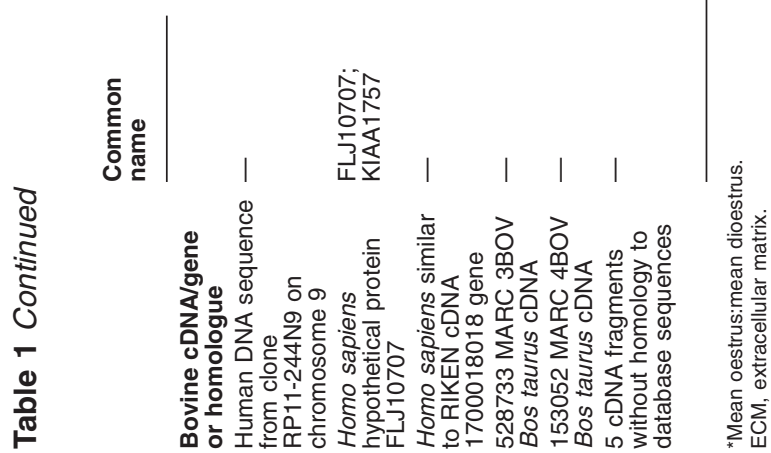

www.endocrinology.org 
GCGATCACTGAACTG-3' [856 bp]) referring to Rief et al. (2002), C3 (for 5'-AAGTTGATGAGGG ACATCAAG-3'; rev 5'-CACTGTTTCTGGTTC TCGTC-3' [191 bp]), MS4A8B (for 5'-CTGAC CTGCTACGAAACGAAC-3'; rev 5'-GCGCA AACAAGGGAGGTATTC-3' [191 bp]) and $18 \mathrm{~S}$ rRNA (for 5'-AAGTCTTTGGGTTCGG GG-3'; rev 5'-GGACA TCTAAGGGCATC ACA-3' [365 bp]) referring to Schoenfelder \& Einspanier (2003).

\section{Reverse transcription and real-time RT-PCR}

One microgram of each sample of total RNA (oestrus $n=3$, dioestrus $n=3$ ) was reverse transcribed in a total volume of $60 \mu \mathrm{l}$ : $5 \times$ buffer (Promega), $10 \mathrm{mM}$ dNTPs (Roche), $50 \mu \mathrm{M}$ hexamer primers (Gibco BRL), $200 \mathrm{U}$ Superscript RT enzyme (Promega). The conventional PGRs were performed in a thermal cycler (Biometra, Göttingen, Germany) as previously described (Schams et al. 2002). All amplified PCR fragments were commercially sequenced to verify the resulting PCR product (MWG-Biotech, Ebersberg, Germany). Thereafter the specific melting point (MP) of the amplified product carried out within the LightCycler standard PCR protocol served as verification of the product identity (Pfaffl et al. 2003). The obtained sequences were subsequently submitted to the EMBL database. For each of the following real-time PGR reactions, $1 \mu \mathrm{l}$ cDNA was used to amplify specific target genes. Quantitative real-time PGR reactions using the LightCycler DNA Master SYBR Green I protocol (Roche) were performed as described previously (Einspanier et al. 2002). In each PGR reaction $17 \mathrm{ng} / \mu \mathrm{l} \mathrm{cDNA}$ were introduced and amplified in a $10 \mu \mathrm{l}$ reaction mixture $\left(3 \mathrm{mM} \mathrm{MgCl}_{2}, 0 \cdot 4 \mu \mathrm{M}\right.$ primer forward and reverse each, $1 \times$ Light Cycler DNA Master SYBR Green I (Roche)). The annealing temperature was $60{ }^{\circ} \mathrm{C}$ for all PGRs. The MP and the appropriate fluorescence acquisition (FA) points for quantification within the fourth step of the amplification segment were as follows: TRAl (MP $81{ }^{\circ} \mathrm{C}, \mathrm{FA} 77^{\circ} \mathrm{C}$ ), ERP70 (MP $88^{\circ} \mathrm{C}, \quad \mathrm{FA} \quad 84^{\circ} \mathrm{C}$ ), GRP78/HSPA5 (MP $85^{\circ} \mathrm{C}$, FA $81{ }^{\circ} \mathrm{C}$ ), AGR2 (MP $83^{\circ} \mathrm{C}$, FA $77^{\circ} \mathrm{C}$ ), OVGP1 (MP $89^{\circ} \mathrm{C}$, FA $85^{\circ} \mathrm{C}$ ), C3 $\left(\mathrm{MP} 89^{\circ} \mathrm{C}\right.$, FA $85^{\circ} \mathrm{C}$ ), MS4A8B (MP $85^{\circ} \mathrm{C}$, FA $81^{\circ} \mathrm{C}$ ), and $18 \mathrm{~S}$ rRNA (MP $88^{\circ} \mathrm{C}, \mathrm{FA} 82^{\circ} \mathrm{G}$ ).

\section{Data analysis of real-time RT-PCR}

The normal distribution of the data was tested by the Kolmogorow-Smirnov method. The significance of differences was evaluated by a $t$-test (Sigma Stat, version 2.03). For all quantitative assays a calibration curve based on a purified PCR product was used. The efficiencies of the specific PGRs were determined as described by Schoenfelder \& Einspanier (2003). Correlation of real-time RT-PGR and cDNA array hybridisation results was calculated using GraphPad Prism version 3.00 for Windows (GraphPad Software, San Diego, CA, USA; www.graphpad.com).

\section{Results}

To analyse the reflections of the morphological changes in the bovine oviduct epithelium on the transcriptional activity we used a combination of subtracted cDNA libraries and cDNA array hybridisation. Two subtracted cDNA libraries were produced for oestrus and dioestrus respectively; 1536 randomly picked cDNA clones of each library were analysed by cDNA array hybridisation. The first array hybridisations showed that many cDNAs were on the array, which produced very strong signals (Fig. 1a) and interfered with the analysis of up to $20 \%$ of all signals. A hybridisation of the arrays with a cDNA probe for the bovine mRNA for $95 \mathrm{kDa}$ OVGP1, which was known to be expressed at very high levels especially at oestrus, showed that approximately 70 of the 3072 cDNAs corresponded to this gene (Fig. 1b). After removal of the OVGP1 cDNA fragments except for one and an additional 142 cDNA fragments that also revealed very strong signals (and no differential expression) the hybridisation signals were much easier to analyse (Fig. 1c). These optimised cDNA arrays were then hybridised with probes of six cyclic heifers (oestrus $n=3$, dioestrus $n=3$ ).

The data analysis revealed 235 cDNA fragments showing significant signal differences between oestrus and dioestrus. In Figure $2 \mathrm{a}$ a scatter plot of the array data for these cDNA fragments is shown. This illustration shows that more cDNA fragments were found in the subtracted libraries, which were up-regulated at oestrus. However, the sequence analyses of these $235 \mathrm{cDNA}$ fragments revealed 37 different genes with higher expression levels at oestrus and 40 with increased expression at 


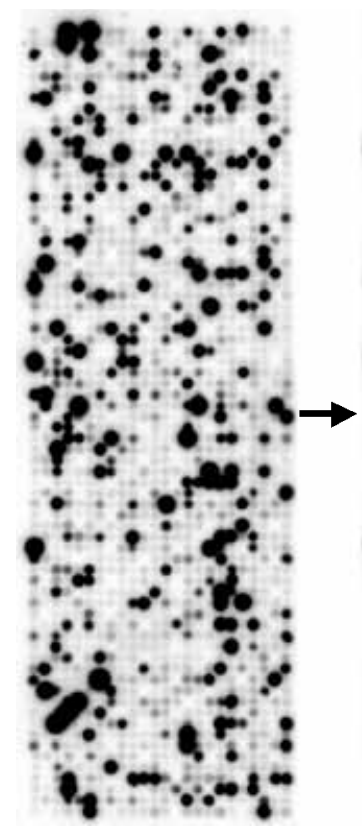

a

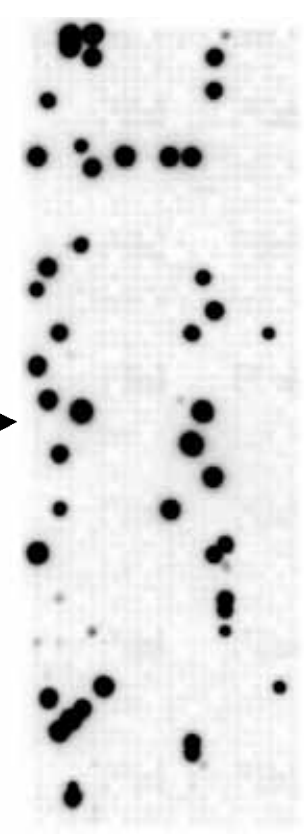

b

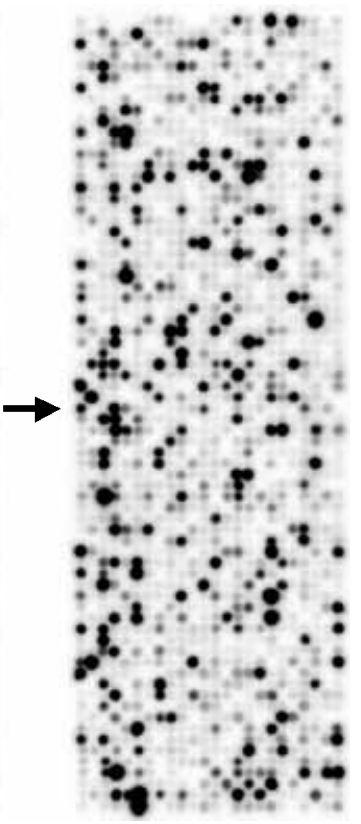

C

Figure 1 Removal of cDNA fragments of highly abundant mRNAs. cDNA array hybridisation yielded for a number of cDNA clones very strong signals, which interfered with the analysis of up to $20 \%$ of all signals (a). To show that many of these cDNAs correspond to the bovine mRNA for $95 \mathrm{kDa}$ OVGP1, arrays were hybridised with a cDNA probe for OVGP1 (b). All but one cDNA for this gene and 142 additional cDNAs, which yielded very strong signals (and no differential expression), were removed from the arrays and cDNA array hybridisation was repeated using this optimised array (c).

dioestrus (Fig. 2b). The average signal ratio was $4 \cdot 8$ for the genes up-regulated at oestrus and $2 \cdot 2$ for those up-regulated at dioestrus. Twenty-one genes were found more than once, most frequently the Bos taurus tumour rejection antigen (gp96) 1 (TRA1) $(n=56)$, the bovine homologue to the Homo sapiens anterior gradient 2 homologue (Xenopus laevis) (AGR2) $(n=24)$ and the Homo sapiens heat shock $70 \mathrm{kDa}$ protein 5 (glucose-regulated protein, $78 \mathrm{kDa})$ (HSPA5) $(n=16)$. For genes that were represented with multiple copies on the array the ratios for the optimal quantifiable signals are shown in the tables rather than the mean of all signal ratios. Nevertheless, the fold differences of the intra-array replicates compared very well. Also, the expression changes revealed by different fragments of one cDNA were quite similar, as observed previously (Bauersachs et al. 2003).

Table 1 lists the cDNAs whose corresponding mRNAs were more abundant in the oviduct epithelial cells at oestrus. The cDNAs are sorted alphabetically by their probable protein function and their signal ratio (descending). The common name, the GenBank accession number, the corresponding UniGene entry, the percent homology to the database sequence, the Gene Ontologies, and the $P$ values are also shown. The signal ratios oestrus:dioestrus were up to 18-fold. Twenty-four of the cDNAs were assigned to genes whose function is known or inferred, mostly to the probable human homologue. For five cDNAs no hit in the GenBank database ('nr' and 'est') was found. In Table 2 the results are shown for the mRNAs, which were more abundant in the oviduct epithelial cells at dioestrus. The greatest difference in gene expression between dioestrus:oestrus was 4.4-fold. Twenty-two of the 40 cDNAs corresponded to genes whose function is known or inferred. Two cDNAs could not be assigned to any sequence in the GenBank database.

The results of the cDNA array hybridisation were verified and absolutely quantified by the use 


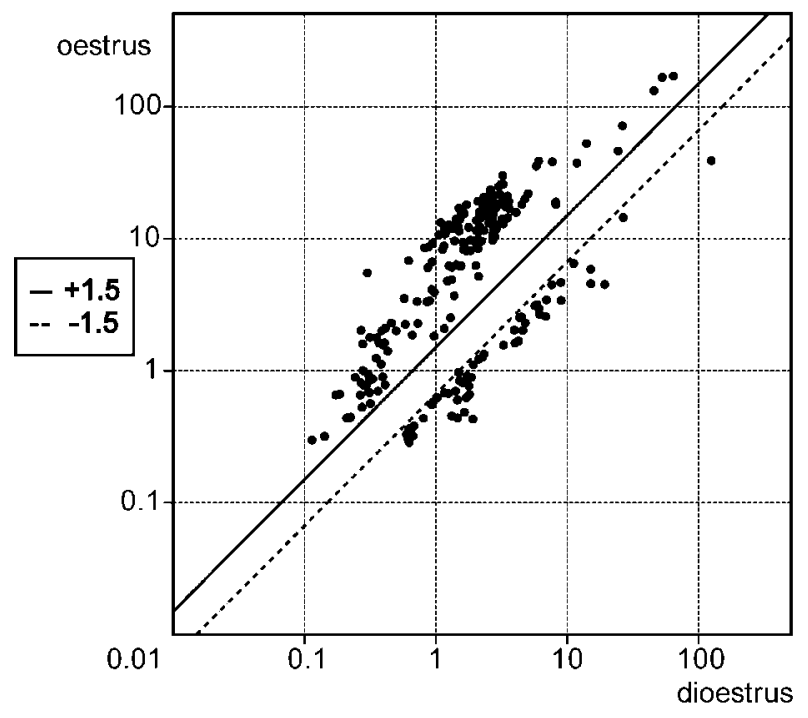

a

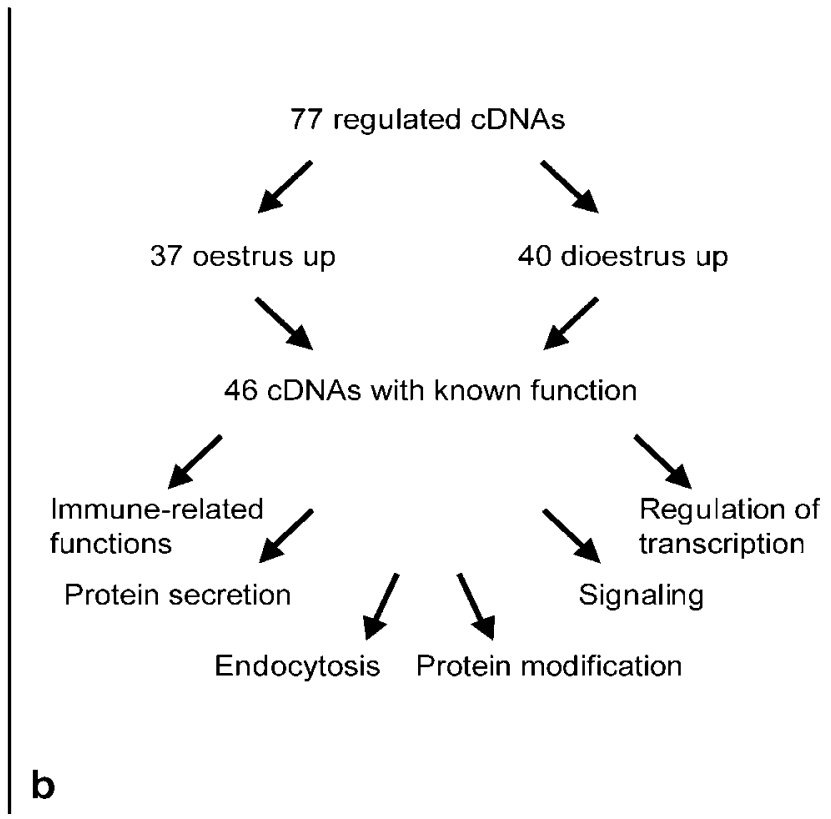

Figure 2 (a) Scatter plot of all differentially expressed cDNA fragments. The mean signals at oestrus (vertical axis) were plotted against the mean signals at dioestrus (horizontal axis) for all 235 differentially expressed cDNA fragments. The lines mark 1.5-fold difference in gene expression. (b) Overview of the identified differentially expressed genes and their assignment to different functional categories.

of real-time RT-PCR. The same six RNA samples (oestrus $n=3$, dioestrus $n=3$ ) as for array hybridisation were used. As standardisation for the gene-specific data generated from the real-time specific approach, the abundance of the $18 \mathrm{~S}$ ribosomal RNA was used that was not different between samples of oestrus and dioestrus (see Table 3). Since we referred the absolute mRNA amounts to the amount of total RNA, similar values for the $18 \mathrm{~S}$ rRNA indicate that similar amounts of total RNA were used for the cDNA synthesis. All seven selected genes that had been found up- or down-regulated at oestrus revealed significant differences in the mRNA quantification approach compared with dioestrus. The mean concentrations of $\mathrm{pg} \mathrm{mRNA} / \mu \mathrm{g}$ total RNA \pm S.E.M., the mean oestrus:dioestrus gene expression differences, and the significance values are provided in Table 3. The mRNA concentrations ranged from $2 \mathrm{pg}$ (AGR2) to $371 \mathrm{pg}$ (OVGP1) per $\mu \mathrm{g}$ total RNA at oestrus. The corresponding concentrations at dioestrus were $0 \cdot 2$ and $70 \mathrm{pg} / \mu \mathrm{g}$ total RNA respectively. Out of the group of selected genes up-regulated at oestrus, the 19-fold increase of TRA1 was highest, whereas a $1 \cdot 7$-fold up-regulation of MS4A8B at dioestrus could be detected representing the least but still significant change of expression. For all transcripts investigated there was a strong correlation between cDNA array hybridisation and real-time RT-PGR data, as illustrated in Fig. 3.

To get a more detailed view of the differentially expressed genes regarding their assignment to functional classes a simplified Gene Ontology for the biological processes and molecular functions was built (Fig. 4). Some of the biological processes and molecular functions were clearly dominated by genes up-regulated either at oestrus or at dioestrus. For example, the biological process 'Protein secretion' was clearly up-regulated at oestrus indicated by seven chaperones and two other proteins located in the endoplasmic reticulum (ER). In contrast, at dioestrus genes involved in transcriptional regulation and genes with immunerelated functions were up-regulated. For other biological processes and molecular functions shown in Fig. 4 the mRNA abundance of identified genes was higher at oestrus or at dioestrus. Further analysis of these groups of genes showed that they belong to different functional subclasses (see Tables 1 and 2). 


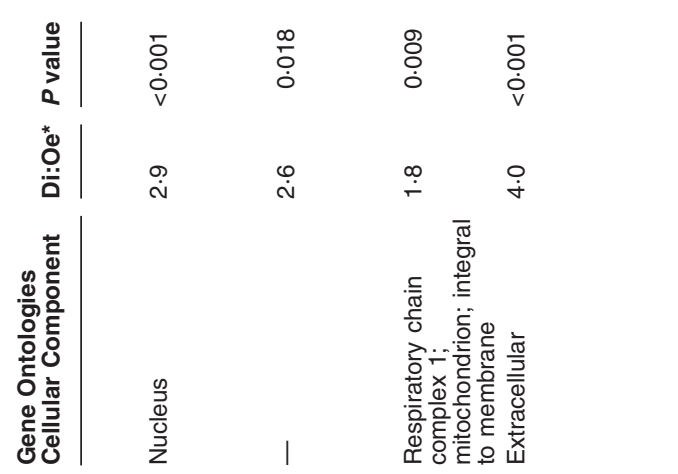

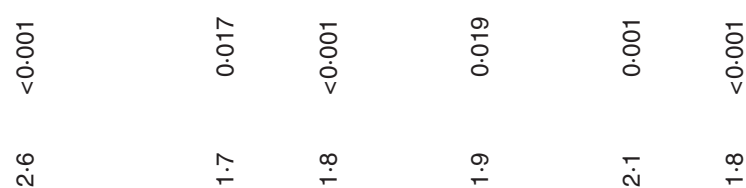
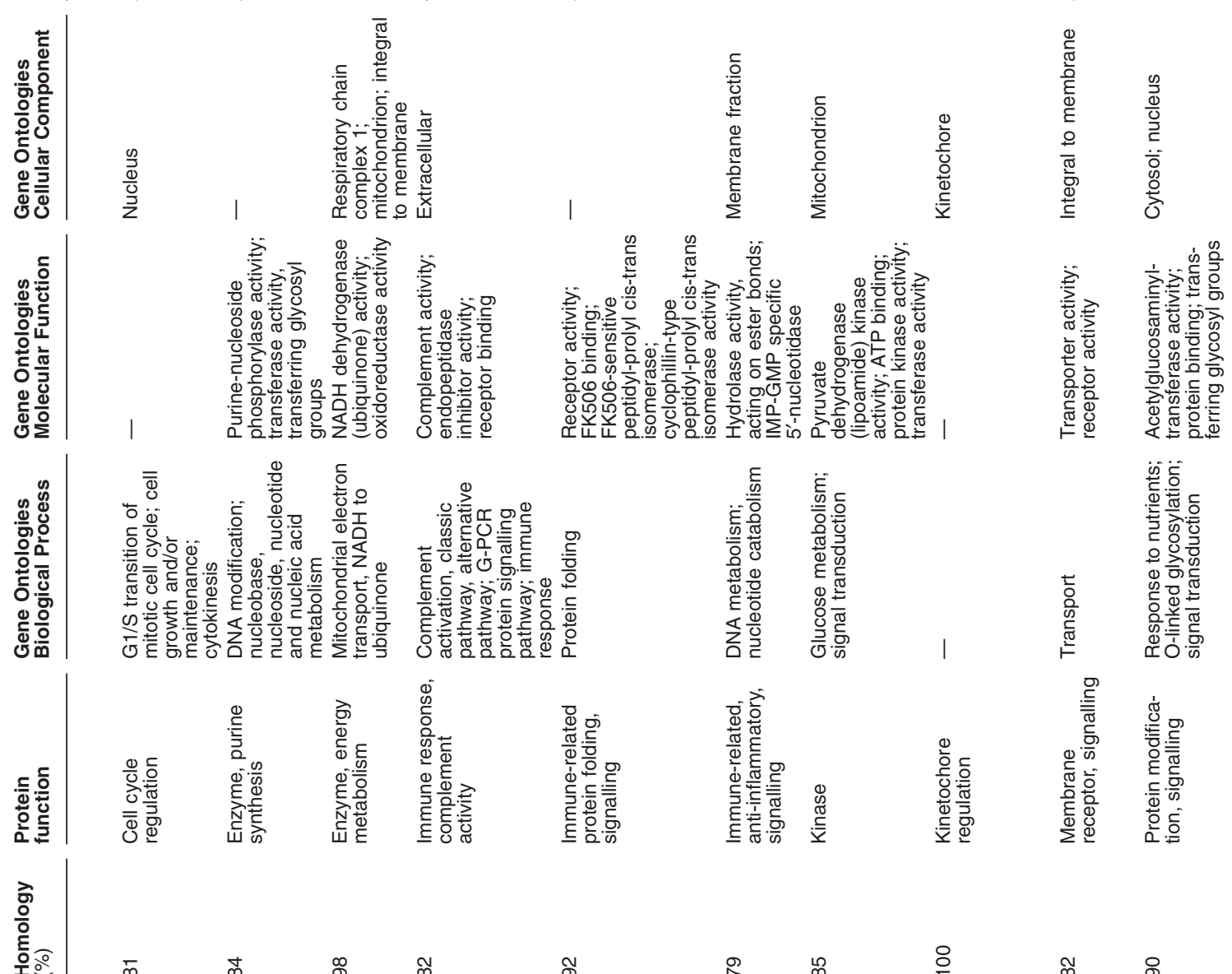

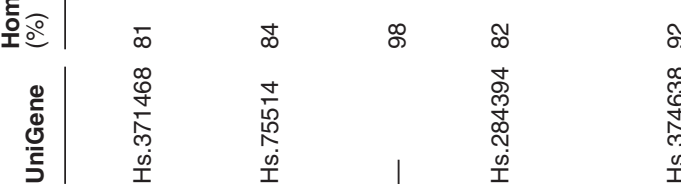
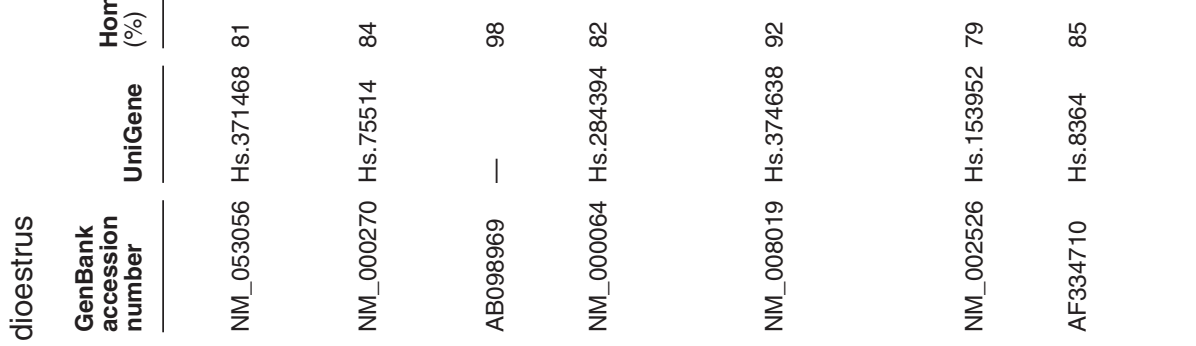

$\stackrel{ }{\circ}$

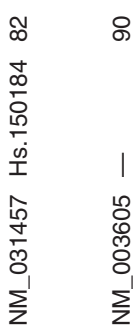
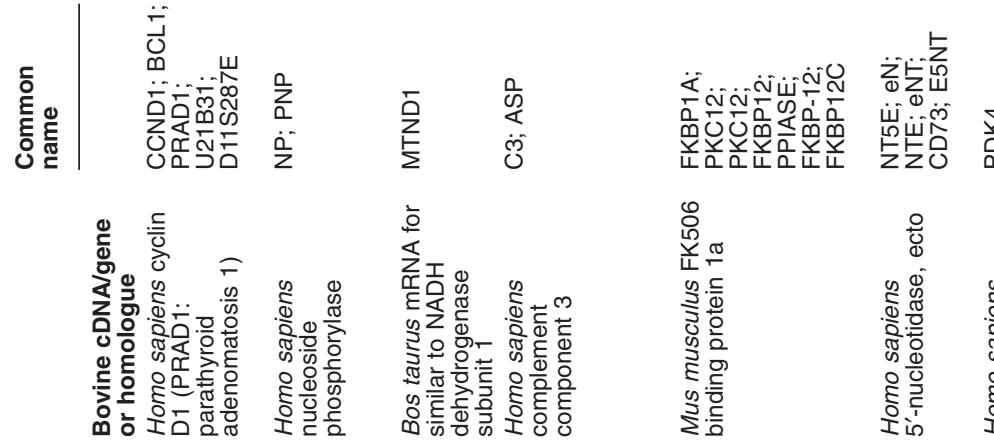

www.endocrinology.org 


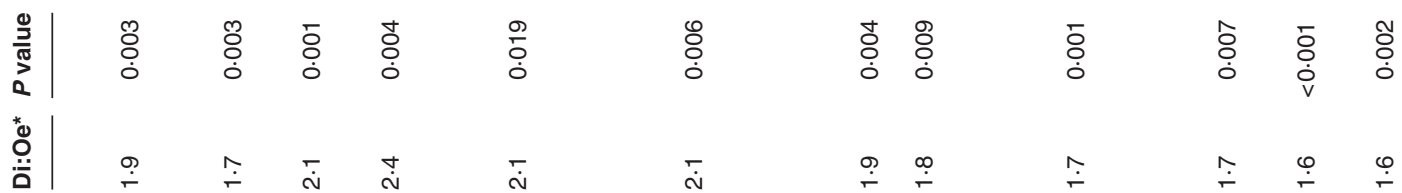
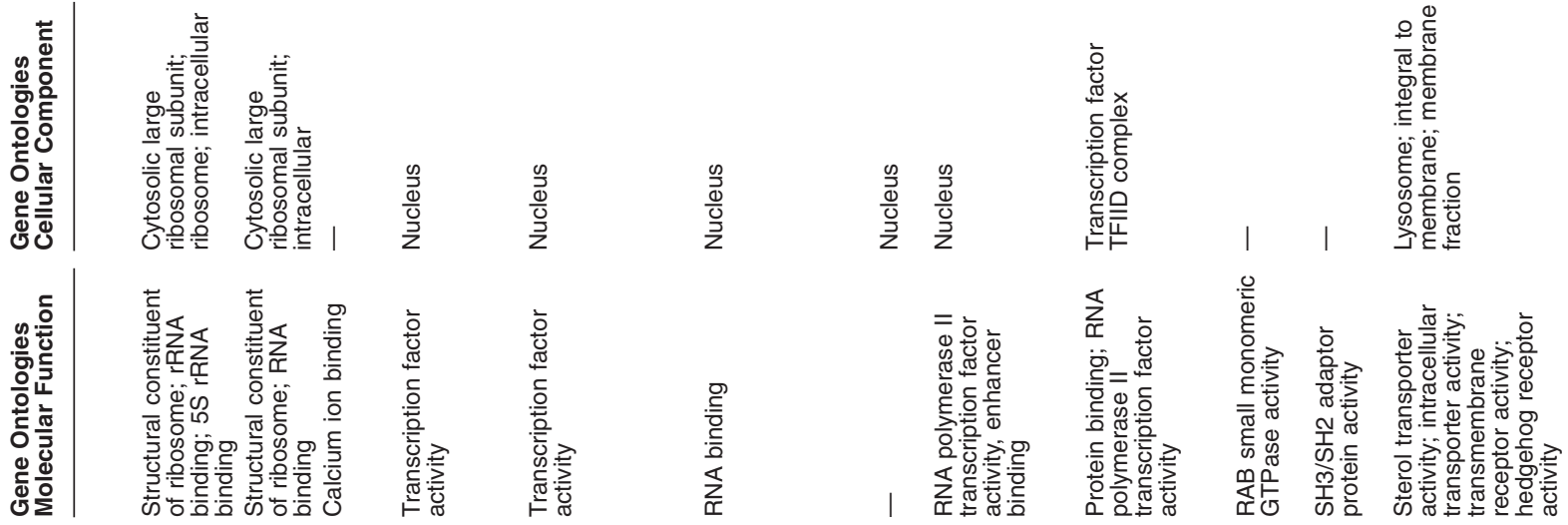

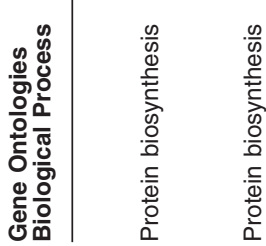
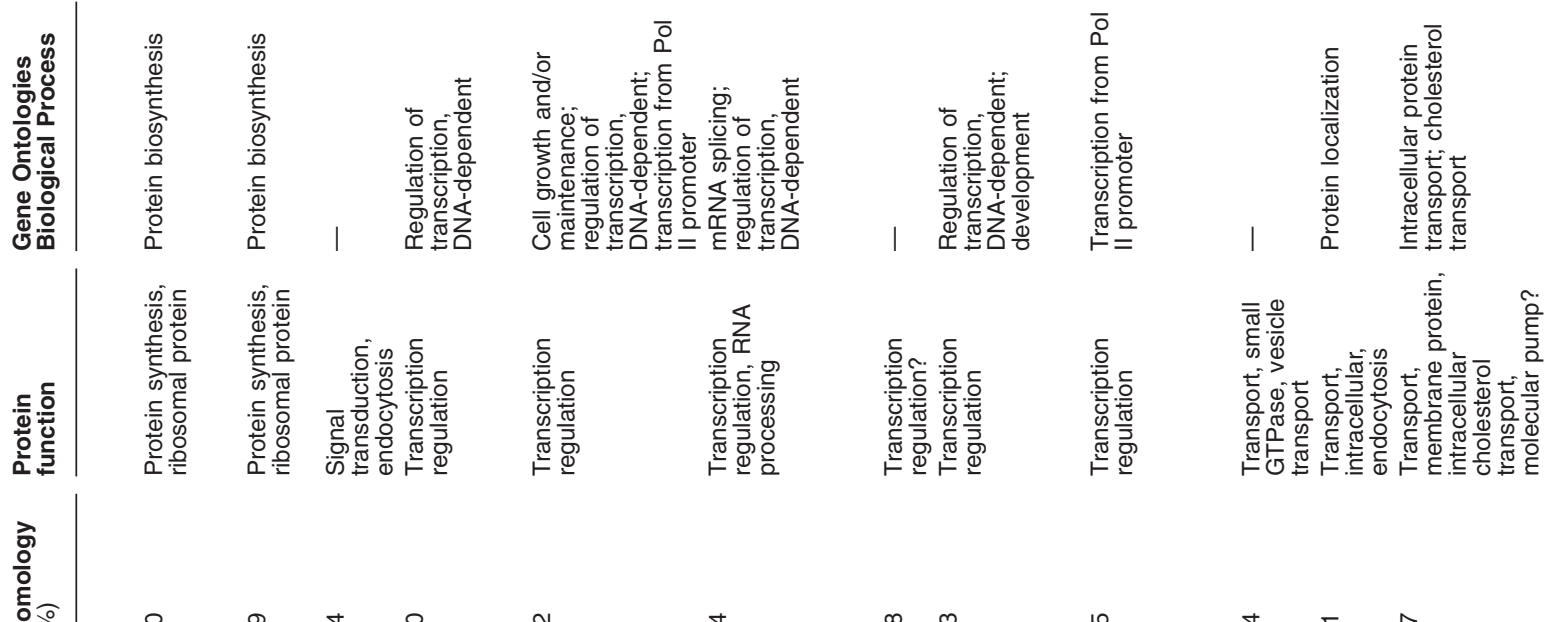

우용 \& \& मे ०

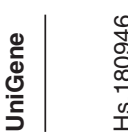

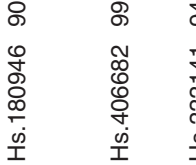

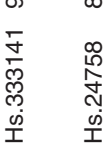

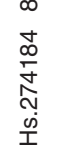

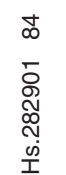

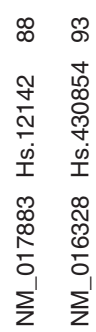

$\stackrel{2}{\circ}$

苾

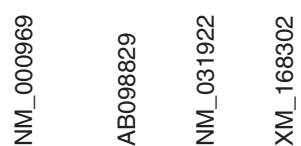

స్․․

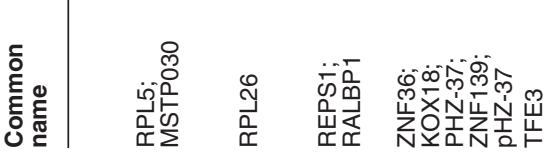

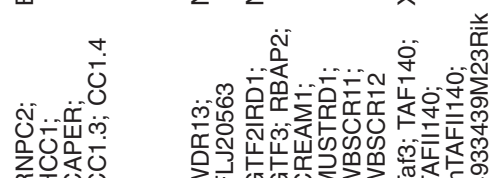

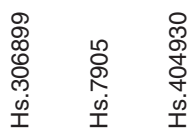

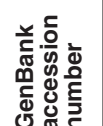

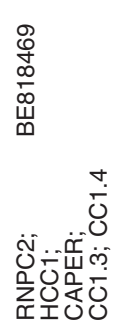

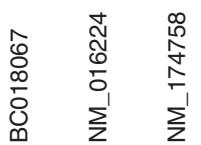

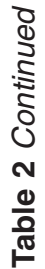

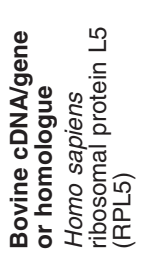

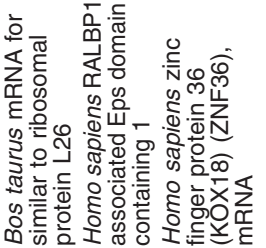

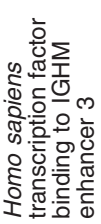

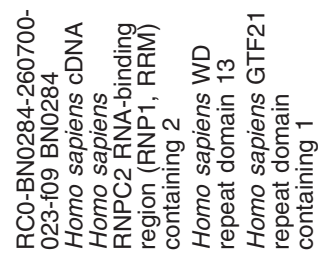

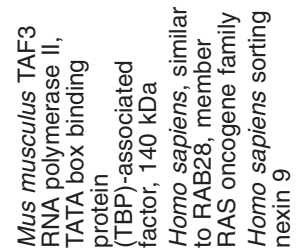

$\ddot{\circ}$

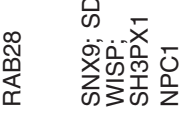




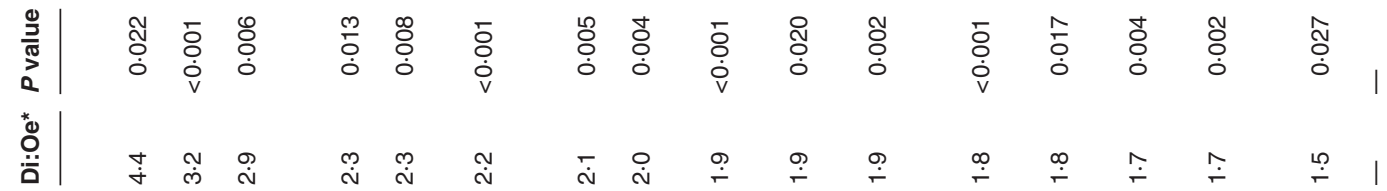
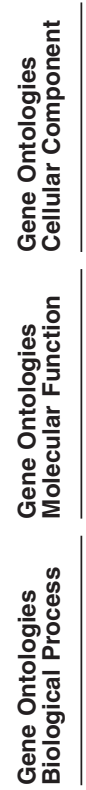

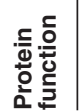

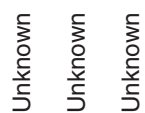

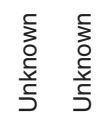

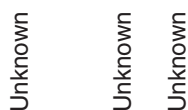

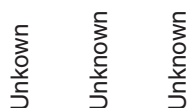

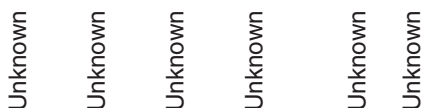

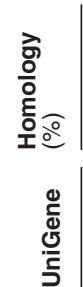

우 \&

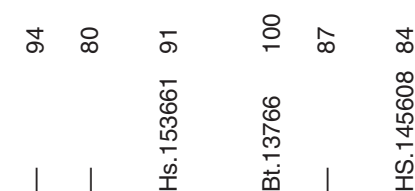

‡

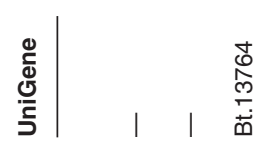

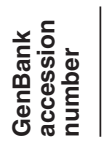

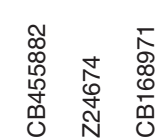

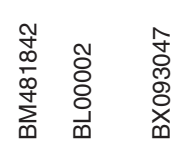

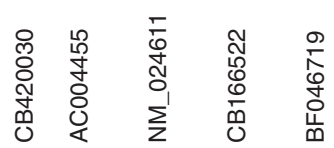

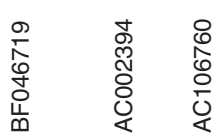

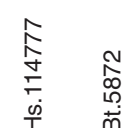

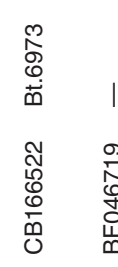

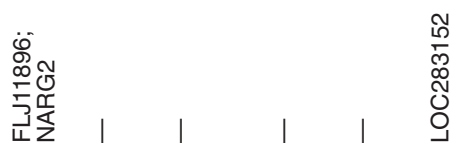

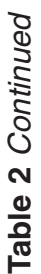

غั.

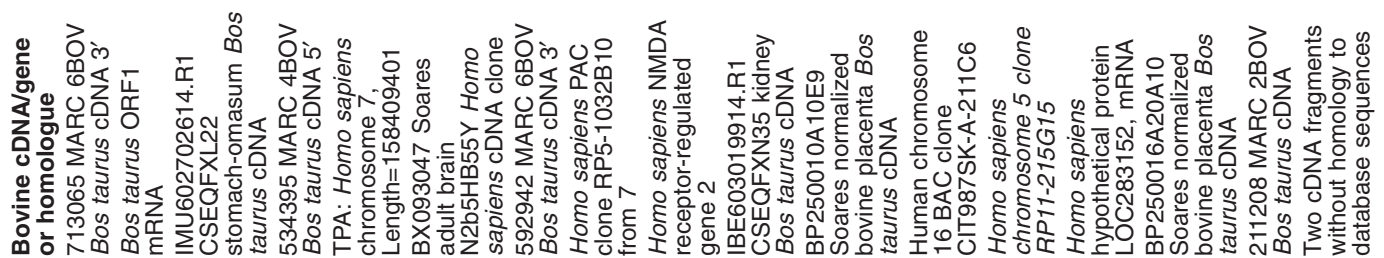

www.endocrinology.org 
Table 3 Results of real-time RT-PCR

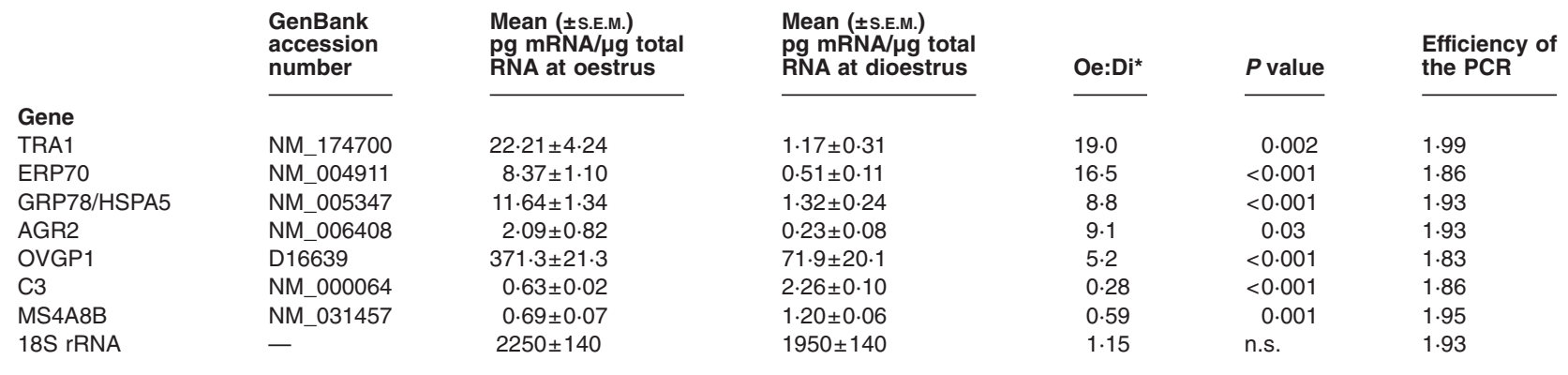

*Mean oestrus:mean dioestrus.

\section{Discussion}

The objective of this study was to investigate differences in gene expression at the mRNA level in the oviduct epithelium between oestrus and dioestrus to get a first view into the complex regulation of gene expression during the oestrous cycle. For the first time differential gene expression in bovine oviduct epithelial cells was systematically investigated to identify genes that might be involved in the morphological and functional changes of these cells. So far, only few studies have been done to investigate systematically the oviduct epithelium through the oestrous cycle. Yaniz et al. (2000) showed that there are changes in the proportions of secretory and ciliated cells during the cycle, especially in the ampulla. As shown previously both mRNA and protein levels of the steroid hormone receptors showed region-specific and cycle-dependent expression differences in the bovine oviduct (Ulbrich et al. 2003).

To identify changes in gene expression, subtracted cDNA libraries were prepared for epithelial cells at oestrus and at dioestrus (enrichment of cDNAs of differentially expressed genes). Subsequently, a set of randomly picked clones (1536 of each library) was analysed by cDNA array hybridisation with probes prepared from oviduct epithelial cells of six cyclic heifers, three at oestrus and three at dioestrus, to evaluate reproducibility and biological variation between individual animals. The analysis of the array data showed in general that the average degree of up-regulation of mRNAs at oestrus was more than 2-fold higher than at dioestrus. Sequencing of the cDNAs that showed differential signals revealed 77 different
mRNAs, of which 37 were up-regulated at oestrus and 40 were more abundant at dioestrus.

To verify the results obtained by cDNA array hybridisation seven genes were selected for absolute quantification using real-time RT-PCR. The analysis of the same RNA samples as used for array hybridisation allowed a direct comparison of both methods. The results of the real-time RT-PCR confirmed clearly the data obtained by array hybridisation as shown by the strong correlation of the data. The observation that ratios found by real-time RT-PCR for genes up-regulated at oestrus were higher and the ratios for the selected two genes up-regulated at dioestrus were slightly lower compared with array hybridisation can be easily explained: for the array hybridisation, a ds hybridisation probe was used. Although hybridisation to the cDNA fragment on the array should be preferred, re-association to ds cDNA in the hybridisation solution can occur. The rate of re-association depends on the concentration of each cDNA, which is higher in the probe where the particular cDNA is more abundant. This effect is enhanced if the concentration of the cDNA spotted on the array is not in very high excess to the corresponding cDNA in the hybridisation solution as in the case of highly expressed genes like OVGP1 or TRA1. Furthermore, the mode of background subtraction and normalisation of the raw data could result in normalised values that are slightly too low or too high. This holds as well for the real-time PGR data. In our study the calculation of the ratios was based on absolute mRNA concentrations. Another possibility is to refer the data to a standard like the $18 \mathrm{~S}$ rRNA. In this case all oestrous values would slightly decrease 

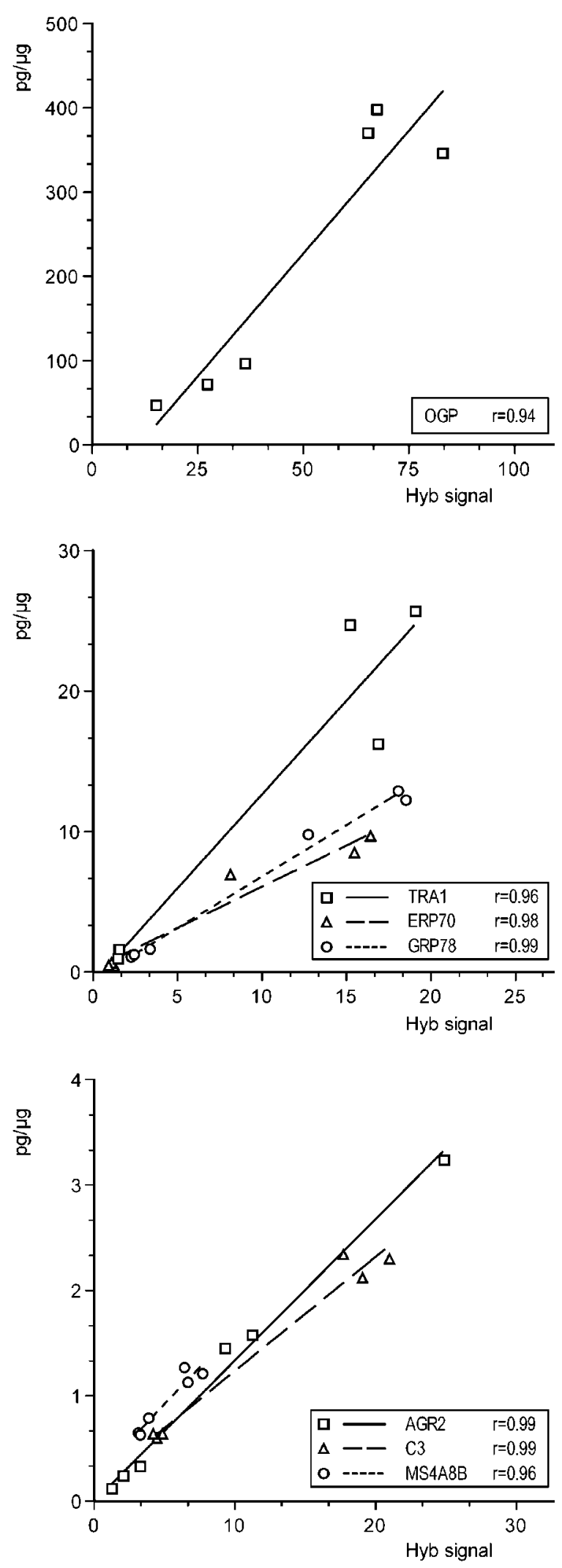

and all dioestrous values would increase resulting in slightly lower oestrus:dioestrus ratios. In the present study though this would not have changed the conclusion. In most studies where array hybridisation and real-time RT-PCR results were compared expression ratios were for some of the investigated genes completely different or ratios obtained by array hybridisation were lower (Rajeevan et al. 2001, Bangur et al. 2002, Jiang et al. 2002 (for review see Chuaqui et al. 2002)). In contrast, in our study the results for all selected genes correlated very well and the array data were clearly confirmed for the selected genes, demonstrating the capability of array hybridisation on nylon membranes using radioactively labelled probes for the identification of differentially expressed genes.

Only a few of the identified genes have already been described in context with the oviduct or other reproductive organs. The cDNA of the major oviductal glycoprotein (OVGP1) showed by far the highest expression in the oviduct epithelium at oestrus compared with the other identified cDNAs. The measured up-regulation of $2 \cdot 7$-fold is certainly low, even the real-time PCR approach revealed only a $5 \cdot 2$-fold up-regulation. This may be due to the sampling procedure not discriminating between the ampulla and the isthmus region of the oviduct. Recently, we found that the abundance of the OVGP1 mRNA was slightly higher in the contralateral oviduct epithelium compared with the ipsilateral oviduct at day 3.5 (Bauersachs et al. 2003). The mRNA of L-plastin, a beta-actinbundling protein (Namba et al. 1992), was also found to be regulated by estrogens and progestins in endometrial stromal cells (Leavitt et al. 1994). For the $78 \mathrm{kDa}$ glucose-regulated protein (GRP78/ HSPA5), a chaperone located in the ER, differential expression in the glandular epithelium of the mouse uterus was described (Simmons \& Kennedy 2000). In our study the expression of the GRP78 mRNA was increased 6-fold at oestrus.

Figure 3 Correlation of array hybridisation and real-time RT-PCR data. Seven selected genes identified as up-regulated at oestrus or dioestrus by CDNA array hybridisation were further analysed by real-time RT-PCR using identical RNA samples as for array hybridisation (oestrus $n=3$, dioestrus $n=3$ ). The mRNA concentrations obtained by real-time RT-PCR (pg mRNA/ $\mu g$ total RNA) and the normalised signals (Hyb signal) were used for the calculation of the correlation coefficient $(r)$. OGP $=$ OVGP1. 
Biological Process

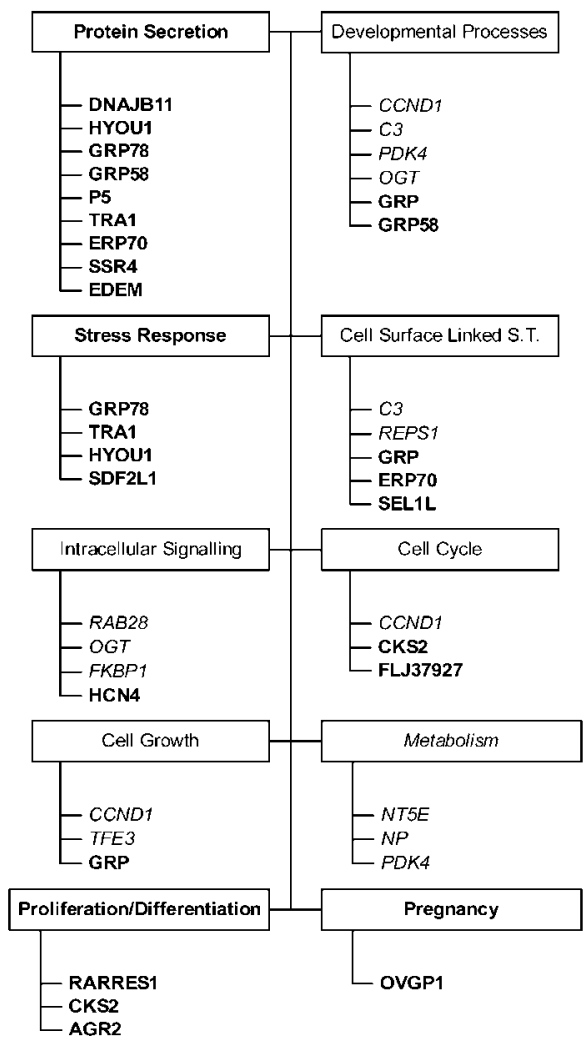

Molecular Function

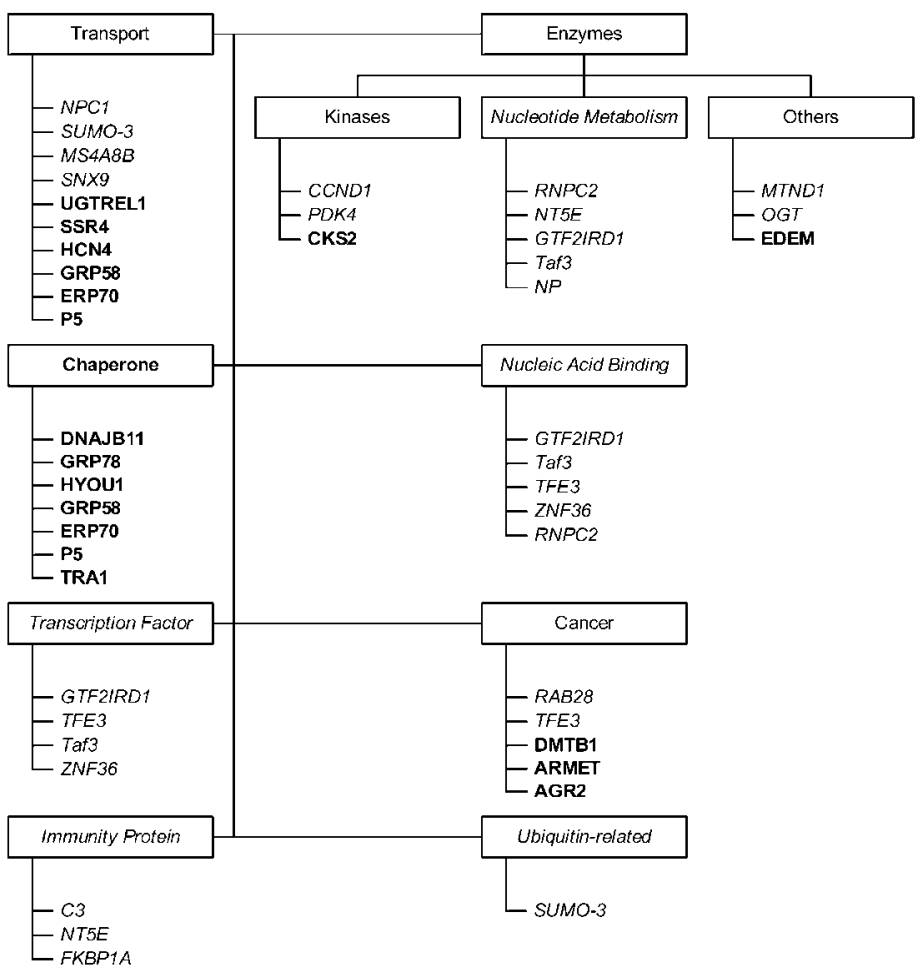

Figure 4 Simplified Gene Ontology. Differentially expressed genes at oestrus and dioestrus were classified using the Simplified Gene Ontology function of GeneSpring and functional data obtained by the database analysis. Gene Ontologies for Biological Processes and for Molecular Functions are shown. Bold: up-regulated at oestrus; Italics: up-regulated at dioestrus.

The anterior gradient homologue (AGR2), that was also up-regulated 6-fold, was first identified in Xenopus laevis as XAG-2 to play a putative role in ectodermal patterning (Aberger et al. 1998). The XAG-2 signalling depends on an intact fibroblast growth factor signal transduction pathway (Aberger et al. 1998). Furthermore, this gene was found to be co-expressed with the oestrogen receptor in an oestrogen receptor-positive breast carcinoma cell line (Thompson \& Weigel 1998), suggesting that it could be an oestrogen-regulated gene. The abundance of the gastrin-releasing peptide (GRP) mRNA was 4-fold higher at oestrus than at dioestrus. GRP belongs to a group of regulatory peptides and was found to be expressed in the reproductive tract of different species (Happola \& Lakomy 1989, Fraser et al. 1994, Whitley et al. 1996, 1998, Budipitoj et al. 2001). In sheep a study of GRP mRNA expression during the oestrous cycle in the uterus showed that expression was markedly increased at day 16 compared with days 4, 10, 12 and 14 (Whitley et al. 1998); day 0 was not investigated. The expression in the uterus was located mainly to the uterine gland epithelial cells (Budipitoj et al. 2001).

Also some of the genes up-regulated in the oviduct epithelial cells at dioestrus have been described in the context of reproduction. The expression of the purine nucleoside phosphorylase mRNA that was up-regulated $2 \cdot 6$-fold was also described in human and mouse endometrium (Kao et al. 2003). Our previous study of bovine oviduct epithelial cells at day 3.5 of the oestrous cycle revealed a 2-fold higher mRNA level of this gene in the ipsilateral compared with the contralateral oviduct (Bauersachs et al. 2003). For the complement component C3 a role in the interaction of human gametes was postulated 
(Anderson et al. 1993). Furthermore, oestrogendependent expression and negative regulation by $\mathrm{P}_{4}$ of the C3 mRNA was shown in the uterus of rats (Brown et al. 1990). However, we found a 4-fold increase in gene expression at dioestrus in the oviduct epithelial cells. The FK506 binding protein 1a, also known as immunophilin FKBP12, has a role in T-cell immunosuppression and it was also shown to increase or initiate the sperm motility in the male reproductive tract (Walensky et al. 1998).

For further interpretation and classification of the results, i.e. of the identified differentially expressed genes, a simplified Gene Ontology was drawn. In general, different functional classes were up-regulated at the two analysed times of the oestrous cycle. The up-regulation of genes involved in protein secretion and of four secreted proteins at oestrus correlates with morphological observations, since more secretory cells are present in the ampulla during oestrus compared with dioestrus (Yaniz et al. 2000). Moreover, a group of genes mediating differentiation and/or suppression of proliferation (e.g. RARRES1, GRP, AGR2, DMTB1) was found to be up-regulated at oestrus. In contrast, at dioestrus genes promoting proliferation and genes involved in transcriptional regulation were slightly up-regulated. Furthermore, the expression of three immune-related genes was increased at dioestrus, indicating changes in the immune regulation during the oestrous cycle. In conclusion, the Gene Ontology classification revealed different phenotypes of the oviduct epithelium, a more differentiated, secretory phenotype at oestrus and a less differentiated at dioestrus. Since these phenotypes are mainly regulated by the ovarian hormones, the results of this study could also be applied to other epithelia whose development is under the control of these ovarian hormones.

In summary, our study is the first that systematically investigated changes in gene expression patterns at the mRNA level in bovine oviduct epithelial cells during the oestrous cycle and provides a starting point for more detailed analyses. The results of the cDNA array hybridisation have been verified and exactly quantified using real-time RT-PCR. Since the oviduct is organised into different functional compartments a next step would be to compare gene expression in these functional units at different times of the oestrous cycle or to assign expression of interesting genes to distinct cells of the oviduct epithelium.

\section{Acknowledgements}

We thank Peter Rieblinger for excellent animal management. Supported by the Deutsche Forschungsgemeinschaft (FOR 478/1).

\section{References}

Aberger F, Weidinger G, Grunz H \& Richter K 1998 Anterior specification of embryonic ectoderm: the role of the Xenopus cement gland-specific gene XAG-2. Mechanisms of Development 72 115-130.

Anderson DJ, Abbott AF \& Jack RM 1993 The role of complement component $\mathrm{C} 3 \mathrm{~b}$ and its receptors in sperm-oocyte interaction. PNAS 90 10051-10055.

Araki Y, Nohara M, Yoshida-Komiya H, Kuramochi T, Ito M, Hoshi H, Shinkai Y \& Sendai Y 2003 Effect of a null mutation of the oviduct-specific glycoprotein gene on mouse fertilization. Biochemical fournal. 374 551-557.

Bangur CS, Switzer A, Fan L, Marton MJ, Meyer MR \& Wang T 2002 Identification of genes over-expressed in small cell lung carcinoma using suppression subtractive hybridization and cDNA microarray expression analysis. Oncogene $213814-3825$.

Bauersachs S, Blum H, Mallok S, Wenigerkind H, Rief S, Prelle K \& Wolf E 2003 Regulation of ipsilateral and contralateral bovine oviduct epithelial cell function in the postovulation period: a transcriptomics approach. Biology of Reproduction 68 1170-1177.

Boice ML, Geisert RD, Blair RM \& Verhage HG 1990 Identification and characterization of bovine oviductal glycoproteins synthesized at estrus. Biology of Reproduction 43 457-465.

Brown EO, Sundstrom SA, Komm BS, Yi Z, Teuscher C \& Lyttle CR 1990 Progesterone regulation of estradiol-induced rat uterine secretory protein, complement C3. Biology of Reproduction 42 713-719.

Budipitoj T, Matsuzaki S, Cruzana MB, Baltazar ET, Hondo E, Sunaryo S, Kitamura N \& Yamada J 2001 Immunolocalization of gastrin-releasing peptide in the bovine uterus and placenta. Fournal of Veterinary Medical Science 63 11-15.

Buhi WC 2002 Characterization and biological roles of oviduct-specific, oestrogen-dependent glycoprotein. Reproduction 123 355-362.

Chuaqui RF, Bonner RF, Best CJ, Gillespie JW, Flaig MJ, Hewitt SM, Phillips JL, Krizman DB, Tangrea MA, Ahram M et al. 2002 Post-analysis follow-up and validation of microarray experiments. Nature Genetics 32 (Suppl) 509-514.

Diatchenko L, Lau YF, Campbell AP, Chenchik A, Moqadam F, Huang B, Lukyanov S, Lukyanov K, Gurskaya N, Sverdlov ED et al. 1996 Suppression subtractive hybridization: a method for generating differentially regulated or tissue-specific cDNA probes and libraries. PNAS 93 6025-6030.

Diatchenko L, Lukyanov S, Lau YF \& Siebert PD 1999 Suppression subtractive hybridization: a versatile method for identifying differentially expressed genes. Methods in Enzymology 303 349-380.

Einspanier R, Schonfelder M, Muller K, Stojkovic M, Kosmann M, Wolf E \& Schams D 2002 Expression of the vascular endothelial growth factor and its receptors and effects of VEGF during in vitro maturation of bovine cumulus-oocyte complexes (COC). Molecular Reproduction and Development 62 29-36. 
Fraser M, McDonald TJ, Spindel ER, Fahy M, Hill D \& Challis JR 1994 Gastrin-releasing peptide is produced in the pregnant ovine uterus. Endocrinology 135 2440-2445.

Gurskaya NG, Diatchenko L, Chenchik A, Siebert PD, Khaspekov GL, Lukyanov KA, Vagner LL, Ermolaeva OD, Lukyanov SA \& Sverdlov ED 1996 Equalizing cDNA subtraction based on selective suppression of polymerase chain reaction: cloning of Jurkat cell transcripts induced by phytohemagglutinin and phorbol 12-myristate 13-acetate. Analytical Biochemistry 240 90-97.

Happola O \& Lakomy M 1989 Immunohistochemical localization of calcitonin gene-related peptide and bombesin/gastrin-releasing peptide in nerve fibers of the rat, guinea pig and pig female genital organs. Histochemistry 92 211-218.

Hunter RH \& Wilmut I 1984 Sperm transport in the cow: peri-ovulatory redistribution of viable cells within the oviduct. Reproduction, Nutrition, Development 24 597-608.

Jiang Y, Harlocker SL, Molesh DA, Dillon DC, Stolk JA, Houghton RL, Repasky EA, Badaro R, Reed SG \& Xu J 2002 Discovery of differentially expressed genes in human breast cancer using subtracted cDNA libraries and cDNA microarrays. Oncogene 21 2270-2282.

Kao LG, Germeyer A, Tulac S, Lobo S, Yang JP, Taylor RN, Osteen K, Lessey BA \& Giudice LC 2003 Expression profiling of endometrium from women with endometriosis reveals candidate genes for disease-based implantation failure and infertility. Endocrinology 144 2870-2881.

Leavitt J, Chen ZP, Lockwood CJ \& Schatz F 1994 Regulation of synthesis of the transformation-induced protein, leukocyte plastin, by ovarian steroid hormones. Cancer Research 54 3447-3454.

Namba Y, Ito M, Zu Y, Shigesada K \& Maruyama K 1992 Human $\mathrm{T}$ cell L-plastin bundles actin filaments in a calcium-dependent manner. Fournal of Biochemistry 112 503-507.

Pfaffl MW, Lange IG \& Meyer HH 2003 The gastrointestinal tract as target of steroid hormone action: quantification of steroid receptor mRNA expression (AR, ERalpha, ERbeta and PR) in 10 bovine gastrointestinal tract compartments by kinetic RT-PCR. Fournal of Steroid Biochemistry and Molecular Biology 84 159-166.

Rajeevan MS, Vernon SD, Taysavang N \& Unger ER 2001 Validation of array-based gene expression profiles by real-time (kinetic) RT-PCR. Fournal of Molecular Diagnostics 3 26-31.

Reischl J, Prelle K, Schol H, Neumuller C, Einspanier R, Sinowatz F \& Wolf E 1999 Factors affecting proliferation and dedifferentiation of primary bovine oviduct epithelial cells in vitro. Cell and Tissue Research 296 371-383.

Rief S, Sinowatz F, Stojkovic M, Einspanier R, Wolf E \& Prelle K 2002 Effects of a novel co-culture system on development, metabolism and gene expression of bovine embryos produced in vitro. Reproduction 124 543-556.

Schams D, Berisha B, Kosmann M \& Amselgruber WM 2002 Expression and localization of IGF family members in bovine antral follicles during final growth and in luteal tissue during different stages of estrous cycle and pregnancy. Domestic Animal Endocrinology 22 51-72.

Schoenfelder M \& Einspanier R 2003 Expression of hyaluronan synthases and corresponding hyaluronan receptors is differentially regulated during oocyte maturation in cattle. Biology of Reproduction 69 269-277.

Simmons DG \& Kennedy TG 2000 Induction of glucose-regulated protein 78 in rat uterine glandular epithelium during uterine sensitization for the decidual cell reaction. Biology of Reproduction 62 $1168-1176$

Suuroia T, Aunapuu M, Arend A \& Sepp E 2002 ['Light' epithelial cells of swine and bovine oviducts]. Tsitologiia 44 656-660.

Thompson DA \& Weigel RJ 1998 hAG-2, the human homologue of the Xenopus laevis cement gland gene XAG-2, is coexpressed with estrogen receptor in breast cancer cell lines. Biochemical and Biophysical Research Communications 251 111-116.

Ulbrich SE, Kettler A \& Einspanier R 2003 Expression and localization of estrogen receptor alpha, estrogen receptor beta and progesterone receptor in the bovine oviduct in vivo and in vitro. Fournal of Steroid Biochemistry and Molecular Biology 84 279-289.

Walensky LD, Dawson TM, Steiner JP, Sabatini DM, Suarez JD, Klinefelter GR \& Snyder SH 1998 The 12 kD FK 506 binding protein FKBP12 is released in the male reproductive tract and stimulates sperm motility. Molecular Medicine 4 502-514.

Whitley JC, Giraud AS \& Shulkes A 1996 Expression of gastrin-releasing peptide (GRP) and GRP receptors in the pregnant human uterus at term. Fournal of Clinical Endocrinology and Metabolism 81 3944-3950.

Whitley JC, Shulkes A, Salamonsen LA, Vogiagis D, Familari M \& Giraud AS 1998 Temporal expression and cellular localization of a gastrin-releasing peptide-related gene in ovine uterus during the oestrous cycle and pregnancy. Fournal of Endocrinology 157 139-148.

Yaniz JL, Lopez-Gatius F, Santolaria P \& Mullins KJ 2000 Study of the functional anatomy of bovine oviductal mucosa. Anatomical Record 260 268-278.

Received in final form 9 December 2003
Accepted 31 December 2003
Made available online as an
Accepted Preprint 16 January 2004 